\title{
A Practical Approach for Determining the Competitive Advantages of a Business
}

\author{
Hakan Butuner \\ Industrial Management and Engineering Co. (IMECO), Istanbul, Turkey \\ Email address: \\ hakan.butuner@imeco-tr.com
}

To cite this article:

Hakan Butuner. A Practical Approach for Determining the Competitive Advantages of a Business. American Journal of Operations Management and Information Systems. Vol. 4, No. 2, 2019, pp. 63-70. doi: 10.11648/j.ajomis.20190402.13

Received: June 9, 2019; Accepted: June 27, 2019; Published: July 9, 2019

\begin{abstract}
If a business is to enjoy a competitive advantage over the long-term it must be one which competitors find that expensive to copy. What will be offered to the marketplace that is unique and valuable is the competitive advantage. The purpose of this paper is helping businesses to answer the questions of "where are we?" and "what are our differential advantages?" in an effective way. This requires using practical and beneficial techniques during the comprehensive internal and comparison analysis. Internal analysis begins with a history of the business and assesses its conformity to overall goals, target groups and general strategies, etc. After identifying the strengths and weaknesses of the business, we then compare them with the key factors in the market development phases (early development, growth, maturity and decline stages), capacities of main competitors (their objectives, strengths and weaknesses, and strategic approaches), and the industry's success factors (such as costs, relationships, knowledge and structure sources of success determinants), for identifying competitive advantages. For determination of the competitive advantages and so through comparison, using comparison worksheets would be very practical and beneficial. In short, this paper helps businesses to find out their competitive advantages by offering them totally new practical and effective analysis techniques.
\end{abstract}

Keywords: Strategy, Competitive Advantages, Comparison Analysis, Internal Analysis, Analysis Techniques

\section{Introduction}

To develop or revise a strategy, a business would identify the few factors on which success will most likely depend [8]. Businesses are looking for the competitive factors that appear most critical for success can vary even among them within the same industry. Now is the time to compare the business' status with meaningful standards to determine which value factors are competitive advantages [10].

Competitive analysis must evaluate a limited number of strengths and weaknesses relative to the opportunities targeted in the business' current and future competitive environment, and identify the competitive advantages of the business accordingly [10].

The purpose of this paper is to help businesses to answer the questions of "where are we?" and "what are our differential advantages?" in an effective way. This requires using practical and beneficial techniques during the comprehensive internal and comparison analysis [1].

Internal analysis [1] begins with a history of the business and lays down the policies followed and performance demonstrated by the business during recent years within the framework of its mission. Thus, the conformity of goods and/or services produced by the business to the overall goals and policies, how the business serves its target group, the general strategies adopted in this respect, etc. are assessed.

After identifying the internal strengths and weaknesses of the business, we then compare them with the key factors in the market development phases, capacities and resources of main competitors, and the industry's success factors, to identify competitive advantages.

\section{Internal Analysis}

While an internal status analysis (Figure 1) is performed within the business, the past performance of business is evaluated as well as its strengths and weaknesses are put forth. The purpose is to identify the potential of the business taking into consideration its existing performance and problems [1]. 
Internal Analysis
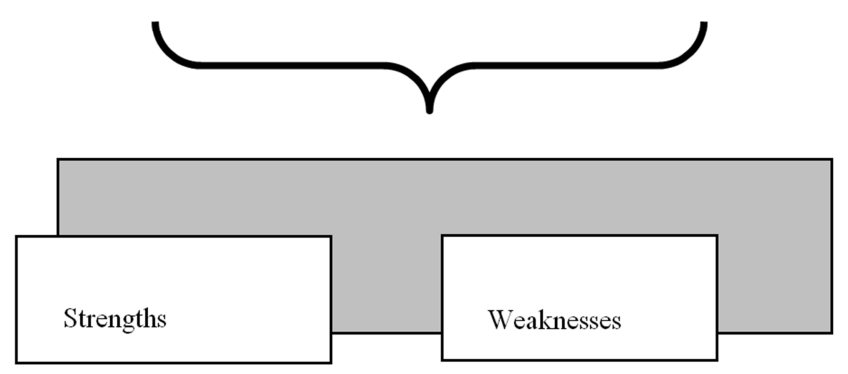

Figure 1. Internal Analysis.

This is accomplished by identifying and then evaluating strategic internal factors. What are strategic internal factors? Where do they originate? How do we decide which are truly strategic factors that must be carefully evaluated? These questions might be raised in identifying and evaluating key internal factors as strengths or weaknesses on which to base the strategy.

Strategic internal factors are a business' basic capabilities, limitations, and characteristics. Diagnosing a business' key strengths and weaknesses requires the adoption of a disaggregated view of the business. Examining the business across distinct functional areas (Table 1) [1], as suggested above is one way to disaggregate the business for internal analysis purposes.

Therefore, the business should examine past performance to isolate key internal contributors to favorable (or unfavorable) results. What did we do well, or poorly, in sales operations, and financial operations that had a major influence on past results? Was the sales force effectively organized? Were we in the right channels of distribution? Did we have the financial resources to support the past strategy?

An example is illustrated on a business history summary worksheet (Table 2) [1]. The same examination and questions can be applied to business' current situation, with emphasis on changes in the importance of key dimensions over time.

For example, analysis of past trends in sales, costs, and profitability is of major importance in identifying strategic internal factors. An anatomy of past trends broken down by product lines, channels of distribution, key customers or types of customers, geographic region, sales approach, etc. should be developed in detail [7]. A business may determine that certain key internal factors (e.g., experience in distribution channels, pricing policies, warehouse location, and technology) deserve major attention in formulating future strategy.

Numerous quantitative tools are available for evaluating selected internal capabilities of a business [5]. These entail measurement of a business' effectiveness vis-a-vis each relevant factor and comparative analysis of this measurement against the historical experience of the business. Ratio analysis is useful for evaluating, selected financial, sales, and operating factors. The business' balance sheet and income statements are important sources from which to derive meaningful ratios. Examples of other quantitative or analytical tools include cash flow analysis, sensitivity analysis, and elasticity and variability analysis.

Table 1. Functional Approach - Example Business.

\begin{tabular}{|c|c|c|}
\hline & FACTORS & $\begin{array}{l}\text { STRENGTHS/ } \\
\text { WEAKNESSES }\end{array}$ \\
\hline \multirow{18}{*}{ MARKETING } & Firm's products /services; breadth of product line & + \\
\hline & Concentration of sales in a few products or to a few customers & - \\
\hline & Ability to gather needed information about markets & + \\
\hline & Market share or submarket shares & + \\
\hline & Product / service mix and expansion potential & + \\
\hline & Channels of distribution: number, coverage and control & + \\
\hline & Effective sales organization & + \\
\hline & Product / service image, reputation and quality & - \\
\hline & Imaginative, efficient and effective sales promotion and advertising & - \\
\hline & Pricing strategy and pricing flexibility & - \\
\hline & Procedures for digesting market feedback and developing new products, services or markets & - \\
\hline & After-sale service and follow up & - \\
\hline & Goodwill/brand loyalty & - \\
\hline & Ability to raise short-term capital & - \\
\hline & Ability to raise long-term capital: debt/equity & + \\
\hline & Corporate-level resources & - \\
\hline & Cost of capital relative to industry and competitors & - \\
\hline & Tax considerations & + \\
\hline \multirow{8}{*}{$\begin{array}{l}\text { FINANCE and } \\
\text { ACCOUNTING }\end{array}$} & Relations with owners, investors and stockholders & + \\
\hline & Leverage positions & + \\
\hline & Cost of entry and barriers to entry & - \\
\hline & Price-earnings ratio & + \\
\hline & Working capital; flexibility of capital structure & - \\
\hline & Effective cost control, ability to reduce costs & + \\
\hline & Financial size & - \\
\hline & Efficient and effective accounting system for cost, budget and profit planning & - \\
\hline PRODUCTION/ & Raw materials cost and availability & - \\
\hline TECHNICAL & Inventory control systems; inventory turnover & - \\
\hline
\end{tabular}




\begin{tabular}{|c|c|c|}
\hline & FACTORS & $\begin{array}{l}\text { STRENGTHS/ } \\
\text { WEAKNESSES }\end{array}$ \\
\hline \multirow{19}{*}{ PERSONNEL } & Location of facilities; layout and utilization of facilities & + \\
\hline & Economies of scale & + \\
\hline & Technical efficiency of facilities and utilization of capacity & + \\
\hline & Effective use of subcontracting & - \\
\hline & Degree of vertical integration, value added and profit margin & + \\
\hline & Efficiency and cost / benefit of equipment & + \\
\hline & Effective operation control procedures & + \\
\hline & Cost and technological competencies relative to industry and competitors & + \\
\hline & Research and development/technology/innovation & + \\
\hline & Patents, trademarks and similar legal protection & + \\
\hline & Management personnel & + \\
\hline & Employees' skill and morale & + \\
\hline & Labor relations cost compared to industry and competition & + \\
\hline & Efficient and effective personnel policies & - \\
\hline & Effective use of incentives to motivate performance & + \\
\hline & Ability to level peaks and valleys of employment & + \\
\hline & Employee turnover and absenteeism & + \\
\hline & Specialized skills & + \\
\hline & Experience & - \\
\hline \multirow{10}{*}{$\begin{array}{l}\text { ORGANIZATION / } \\
\text { GENERAL } \\
\text { MANAGEMENT }\end{array}$} & Organizational structure & - \\
\hline & Firm's image and prestige & - \\
\hline & Firm's record for achieving objectives & - \\
\hline & Organization of communication system & + \\
\hline & Overall organizational control system & + \\
\hline & Organizational climate, culture & - \\
\hline & Use of systematic procedures and techniques in decision making & - \\
\hline & Top-management skill, capacities and interest & + \\
\hline & Strategic planning system & + \\
\hline & Interorganizational synergy & + \\
\hline
\end{tabular}

Quantitative tools cannot be applied to all internal factors, and the judgments of key planning participants may be used in evaluation. Company or product image and prestige are examples of internal factors more appropriate to qualitative evaluation [4].

Table 2. Business History Summary - Example Business.

\begin{tabular}{|c|c|c|c|c|}
\hline & $\begin{array}{l}\text { YEAR } \\
2012\end{array}$ & $\begin{array}{l}\text { YEAR } \\
2013\end{array}$ & $\begin{array}{l}\text { YEAR } \\
2014\end{array}$ & $\begin{array}{l}\text { YEAR } \\
2015\end{array}$ \\
\hline $\begin{array}{l}\text { PERSONNEL } \\
\text { ORGANIZATION and } \\
\text { GENERAL MANAGEMENT }\end{array}$ & & $\begin{array}{l}\text { No. of employees: } 5 \\
4 \text { Clerks, } \\
5 \text { Labors }\end{array}$ & $\begin{array}{l}\text { No. of employees: } 10 \\
5 \text { Clerks, } \\
5 \text { Labors }\end{array}$ & $\begin{array}{l}\text { No. of employees: } 40 \\
15 \text { Clerks, } \\
25 \text { Labors } \\
\text { A flexible organization chart } \\
\text { Production and R\&D dept. } \\
\text { Sales dept. } \\
\text { Dealer network } \\
\text { After-sales dept. }\end{array}$ \\
\hline $\begin{array}{l}\text { PRODUCTION/ } \\
\text { TECHNICAL }\end{array}$ & & Order based production (JIT) & Improved delivery dates & $\begin{array}{l}\text { Increased } \\
\text { production lines and capacity }\end{array}$ \\
\hline MARKETING & & & $\begin{array}{l}\text { Delivered demo units to major } \\
\text { hospitals and rehabilitation centers } \\
\text { Face-to-face selling and } \\
\text { demonstrations }\end{array}$ & $\begin{array}{l}\text { Increased brand awareness } \\
\text { Attended to local fairs and } \\
\text { advertised on the industrial } \\
\text { magazines } \\
\text { Established local dealer network }\end{array}$ \\
\hline $\begin{array}{l}\text { FINANCE and } \\
\text { ACCOUNTING } \\
(x 1000)\end{array}$ & & $\begin{array}{l}0.05 \% \text { of Turkish wheelchair } \\
\text { market, } 50 \text { units sold }\end{array}$ & $\begin{array}{l}0,5 \% \text { of the Turkish wheel chair } \\
\text { market, } 500 \text { units sold }\end{array}$ & $\begin{array}{l}2.5 \% \text { of the Middle Eastern and } \\
\text { Caucasian wheel chair markets; } \\
10.000 \text { units sold }\end{array}$ \\
\hline
\end{tabular}

The considerations revealed by functional approach are grouped under various functional headings such as general management, human resources, operations/technology, marketing, finance and accounting, and their distinction as things done well and poorly are outlined in a summary table [1].

\section{Identifying Competitive Advantages}

Now is the time to compare the business' status with meaningful standards to determine which value factors are competitive advantages etc. Competitive analysis must evaluate a limited number of strengths and weaknesses 
relative to the opportunities targeted in the business' current and future competitive environment, and identify the competitive advantages of the business [10].

A factor is considered a competitive advantage if it is something the business does (or has the future capacity to do) particularly well relative to abilities of existing or potential competitors. Firm gains competitive advantage by performing these strategically important factors more cheaply or better than its competitors. A competitive advantage is present if the business consistently offers the customer something which is different to what competitors are offering, and that difference represents something valuable for the customer [6].

A factor is considered a weakness if it is something the firm does poorly or doesn't have the capacity to do although key rivals have the capacity.

How should the key internal factors be evaluated and valued as competitive advantages or weaknesses? Identifying competitive factors requires an external focus. When key internal factors through analysis of past and present performance are isolated, next step is to identify industry conditions/trends and compare with competitors. Changing industry conditions can lead to the need to reexamine internal strengths and weaknesses in light of newly emerging determinants of success in the industry [9].

To develop or revise a strategy, a business would identify the few factors on which success will most likely depend. Businesses are looking for the competitive factors that appear most critical for success can vary even among them within the same industry.

First, key aspects of the business's operation to the firm's strategic direction called strategic internal factors are audited and examined (Figure 2) [9]. Then evaluate the business' status on these factors by comparing their current condition with past abilities of the business.

Businesses seek some comparative basis-linked to key industry or product/market conditions-against which to more accurately determine whether the business' condition on a factor represents potential competitive advantages or weaknesses. As it is said, businesses use three perspectives to do this; (1) requirements for success across different product/market stages of evolution, (2) what competitors are capable of doing, and (3) perceived key requirements for success in which they compete.
For determination of the competitive advantages and so through comparison, using comparison worksheet [2] would be practical and beneficial (Table 3 ).

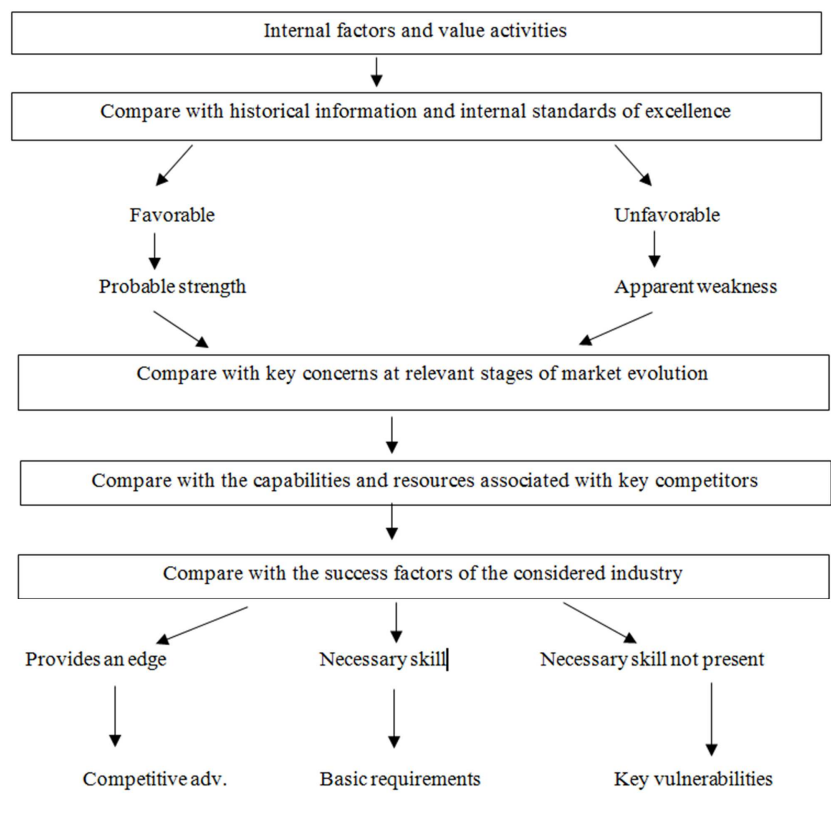

Source: Pearce et. al. 2011

Figure 2. Competitive Advantages and Success Factors.

The result of all should be a determination of whether key internal factors are:

a Competitive advantages: Factors providing the business with an edge compared to its competitors, thus key factors around which to build the business' strategy.

b Basic business requirements: Factors that are important capabilities for the business to have but are also typical of every viable competitor: does not represent a potential source of any strategic advantage.

c Key vulnerabilities: Factors on which the business currently lacks the necessary skill, knowledge, or resources to compete effectively. This assessment is also a key input because businesses will want to avoid choosing strategies that depend on factors in this category. And businesses usually target key vulnerabilities as areas for special attention so as to remediate and change this situation.

Table 3. Comparison with Competitors and Industry Average-Example Business.

\begin{tabular}{|c|c|c|c|c|c|}
\hline & FACTORS & OUR BUSINESS & COMP. X & COMP. Y & $\begin{array}{l}\text { INDUSTRY } \\
\text { AVG. }\end{array}$ \\
\hline \multirow{10}{*}{ MARKETING } & Firm's products /services; breadth of product line & + & + & - & - \\
\hline & Concentration of sales in a few products or to a few customers & & & & \\
\hline & Ability to gather needed information about markets & + & + & + & + \\
\hline & Market share or submarket shares & - & + & + & + \\
\hline & Product / service mix and expansion potential & + & + & - & - \\
\hline & Channels of distribution: number, coverage and control & - & + & + & + \\
\hline & Product / service image, reputation and quality & - & + & - & - \\
\hline & Imaginative, efficient and effective sales promotion and advertising & + & - & - & - \\
\hline & Pricing strategy and pricing flexibility & + & - & + & + \\
\hline & Procedures for digesting market feedback and developing new & + & + & + & + \\
\hline
\end{tabular}




\begin{tabular}{|c|c|c|c|c|c|}
\hline & FACTORS & OUR BUSINESS & COMP. $\mathrm{X}$ & COMP. Y & $\begin{array}{l}\text { INDUSTRY } \\
\text { AVG. }\end{array}$ \\
\hline \multirow{16}{*}{$\begin{array}{l}\text { FINANCE and } \\
\text { ACCUONTING }\end{array}$} & products, services or markets & & & & \\
\hline & After-sale service and follow up & - & - & - & - \\
\hline & Goodwill/brand loyalty & - & - & - & - \\
\hline & Ability to raise short-term capital & - & + & + & + \\
\hline & Ability to raise long-term capital: debt/equity & - & + & + & + \\
\hline & Corporate-level resources & - & + & + & + \\
\hline & Cost of capital relative to industry and competitors & + & - & - & - \\
\hline & Tax considerations & + & - & - & - \\
\hline & Relations with owners, investors and stockholders & + & - & + & - \\
\hline & Leverage positions & + & - & - & - \\
\hline & Cost of entry and barriers to entry & - & + & + & + \\
\hline & Price-earnings ratio & + & + & + & + \\
\hline & Working capital; flexibility of capital structure & - & + & + & + \\
\hline & Effective cost control, ability to reduce costs & + & - & - & - \\
\hline & Financial size & - & + & + & + \\
\hline & $\begin{array}{l}\text { Efficient and effective accounting system for cost, budget and profit } \\
\text { planning }\end{array}$ & + & + & - & - \\
\hline \multirow{12}{*}{$\begin{array}{l}\text { PRODUCTION/ } \\
\text { TECHNICAL }\end{array}$} & Raw materials cost and availability & - & + & - & - \\
\hline & Inventory control systems; inventory turnover & - & + & + & - \\
\hline & Location of facilities; layout and utilization & + & - & + & - \\
\hline & Economies of scale & - & + & + & + \\
\hline & Technical efficiency of facilities and utilization of capacity & - & + & + & + \\
\hline & Effective use of subcontracting & + & - & - & - \\
\hline & Degree of vertical integration, value added and profit margin & + & - & - & - \\
\hline & Efficiency and cost / benefit of equipment & + & - & - & - \\
\hline & Effective operation control procedures & + & + & - & - \\
\hline & $\begin{array}{l}\text { Cost and technological competencies relative to industry and } \\
\text { competitors }\end{array}$ & + & - & - & - \\
\hline & Research and development/technology/innovation & + & + & - & - \\
\hline & Patents, trademarks and similar & + & + & - & - \\
\hline \multirow{9}{*}{ PERSONNEL } & Management personnel & + & + & - & - \\
\hline & Employees' skill and morale & + & + & - & - \\
\hline & Labor relations cost compared to industry and competition & + & - & - & - \\
\hline & Efficient and effective personnel policies & + & - & - & - \\
\hline & Effective use of incentives to motivate performance & + & - & - & - \\
\hline & Ability to level peaks and valleys of employment & - & + & + & + \\
\hline & Employee turnover and absenteeism & + & + & + & + \\
\hline & Specialized skills & + & + & - & - \\
\hline & Experience & + & + & + & + \\
\hline \multirow{10}{*}{$\begin{array}{l}\text { ORGANIZATIO } \\
\text { N / GENERAL } \\
\text { MANAGEMEN } \\
\text { T }\end{array}$} & Organizational structure & + & + & - & - \\
\hline & Firm's image and prestige & - & + & + & + \\
\hline & Firm's record for achieving objectives & - & + & + & + \\
\hline & Organization of communication system & - & + & + & - \\
\hline & Overall organizational control system & - & + & + & - \\
\hline & Organizational climate, culture & - & + & - & - \\
\hline & Use of systematic procedures and techniques & - & + & - & - \\
\hline & Top-management skill, capacities and interest & + & + & - & - \\
\hline & Strategic planning system & + & + & - & - \\
\hline & Interorganizational synergy & + & + & - & - \\
\hline
\end{tabular}

Therefore, based on the above given definitions, a summary working form [2] can be used for determining and listing the competitive advantages, success factors and key vulnerabilities of a business (Table 4).

\subsection{Comparison with Basic Factors of Industry Life Cycle}

The requirements for success in market segments evolve [11] and change over time for identifying and evaluating the business' strengths and weaknesses.

Table 4. Competitive Advantages, Key Vulnerabilities and Success Factors - Example.

\begin{tabular}{lll}
\hline & FACTORS & COMPETITIVE \\
& KDEy Vulnerabılities & $\begin{array}{l}\text { SUCCESS } \\
\text { FACTORS }\end{array}$ \\
\hline ORGANIZATION/ & 1. Flexible and horizontal relations facilitate decision & \\
general & making & \\
MANAGEMENT & 2. Participatory and sharing management \\
& 3. Broad investment vision & \\
\hline
\end{tabular}




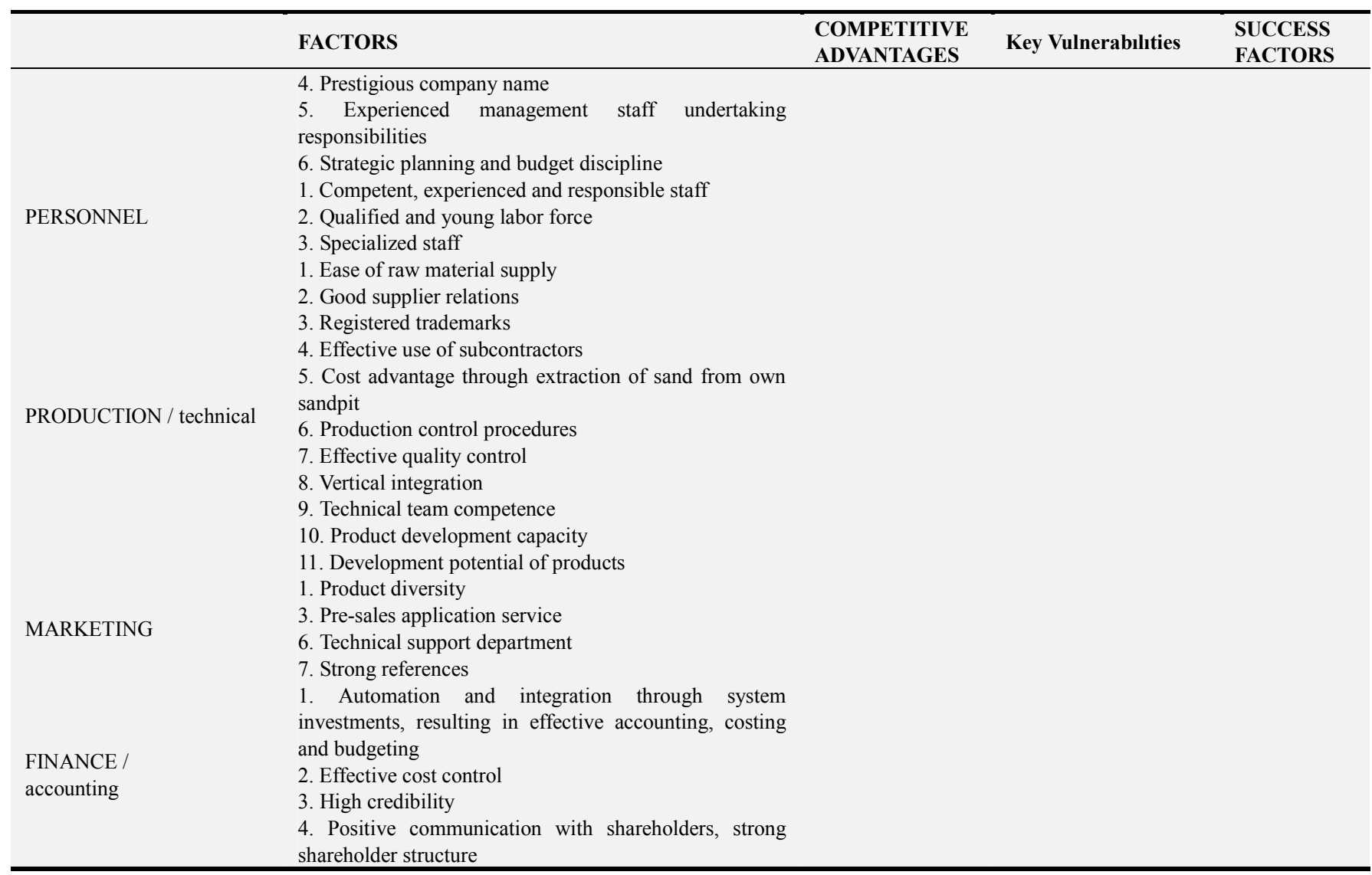

The early development of a market, for example, entails minimal growth in sales, major R\&D emphasis, rapid technological change in the product, operating losses, and a need for sufficient resources or slack to support a temporarily unprofitable operation. Success at this stage may be associated with technical skill with being first in new markets or with having a marketing advantage that creates widespread awareness.

The strengths necessary for success change in the growth stage. Rapid growth brings new competitors into the market. Such factors as brand recognition, product/market differentiation, and the financial resources to support both heavy marketing expenses and the effect of price competition on cash flow can be key strengths at this stage.

In the maturity stage, market growth continues but at a decreasing rate. The number of market segments begins to expand, while technological change in product design slows considerably. The result is usually more intense competition and promotional or pricing advantages or differentiation become key internal strengths. Technological change in process design becomes intense as the many competitors seek to provide the product in the most efficient manner. Where R\&D was critical in the development stage, efficient production has now become crucial to a business's continued success in the broader segments.

In saturation/decline stage, strengths and weaknesses center on cost advantages, superior supplier or customer relationships and financial control. The relative importance of various determinants of success differs across stages of market evolution.

\subsection{Comparison with Main Competitors}

A major focus in determining a business' competitive power and weaknesses is comparison with existing (and potential) competitors. Businesses in the same industry often have different marketing skills, financial resources, operating facilities and locations, technical know-how, brand image, levels of integration, managerial talent, etc. These different internal capabilities can become relative strengths (or weaknesses) depending on the strategy the business chooses. A business should compare capabilities with those of its rivals, thereby isolating key strengths and weaknesses [10].

Strategies and objectives of competitors: The most important competitors of a business are the ones that present products/services to the same target audience with similar strategy. This group of companies is called strategic group.

Determination of the strategic groups will provide more accurate competition definition. The businesses within the same strategic group are more similar than other businesses within the industry, and thus the competition among them is stronger.

The business should have as much information as possible regarding marketing, production, $\mathrm{R} \& \mathrm{D}$, financial and human resources strategies; product qualities; distribution channels; etc. of their competitors.

After determining the competitors' strategies, objectives, growth/merging plans (market share, profitability, 
technological leadership, service leadership, etc.) of the competitors should also be investigated.

Strengths and weaknesses of competitors: The ability of competitors to apply their strategies and reach their objectives depends on their sources and abilities. To define the strengths and weaknesses of competitors, the business shall reach some competitors and assemble information regarding their new investments and assumptions.

The information can be obtained from secondary sources, personal experiences, speeches and also can be composed by the market researches where the customers and suppliers are included.

Strategic approaches of competitors: In general, the companies within an industry can be grouped under four categories with respect to their strategic characteristics [3].

1 Defenders: These companies try to decrease their costs by making their operations more efficient and try to defend their positions in the market.

2 Entrepreneurs: These are companies that continuously create new products/services and new market opportunities.

3 Analyzers: These are companies that act sometimes like defenders and sometimes like entrepreneurs.

4 Followers: These are companies that do not have a specific strategy and act according to the environmental pressures.

\subsection{Comparison with Industry Success Factors}

The key determinants of success in an industry may be used to identify the internal competitive power and weaknesses of a business. Use of industry average to evaluate a business' capacity for success has become a popular technique. Sources of success factors are as follows [12]:

1 The architecture of the business, that is its internal structure

2 The reputation of the business, that is the way key stakeholders view it

3 The way the business innovates, that is its ability to come up with valuable ideas

4 The business's strategic assets that is valuable assets to which it has access

They can be related to four specific sources of success determinants; costs, knowledge, relationships and structure [12].

Cost sources:

1 Lower input costs

2 Economies of scale

3 Experience curve economies

4 Technological innovation

Knowledge sources:

1 Product knowledge

2 Market knowledge

3 Technical knowledge

Relationship sources:

1 Relationship with customers

2 Relationship with suppliers

3 Relationship with investors

4 Relationship with employees

\section{Structural sources:}

Structural advantages arise as a consequence not so much of what the business does but the way it goes about doing things. This is a function not only of its formal structure, the pre-defined way in which individuals will relate to each other but also in its informal structure, the unofficial web of relationships and communication links which actually define it and its culture which governs how those relationships will function and evolve. This should be more responsive to the needs of customers and quicker to offer new products and services.

\section{Conclusion}

To develop or revise a strategy, a business would identify the few factors on which success will most likely depend. Businesses are looking for the competitive factors that appear most critical for success can vary even among them within the same industry. Competitive analysis must evaluate a limited number of strengths and weaknesses relative to the opportunities targeted in the business' current and future competitive environment, and identify the competitive advantages of the business accordingly.

In order to identify the competitive advantages of a business, first determine the internal strengths and weaknesses of the business. Internal analysis begins with a history of the business and lays down the policies followed and performance demonstrated by the business during recent years within the framework of its mission. Thus, the conformity of goods and/or services produced by the business to the overall goals and policies, how the business serves its target group, the general strategies adopted in this respect, etc. are assessed.

Afterwards, compare the business' status with meaningful standards to determine which value factors are competitive advantages etc. In other words, the internal strengths of the business should be compared with the key factors in the market development phases, capacities and resources of main competitors, and the industry's success factors.

Doing so, businesses should find ways to answer the questions of "where are we?" and "what are our differential advantages?" in an effective way. This requires using practical and beneficial techniques during the comprehensive internal and comparison analysis.

Accordingly, the purpose of this paper comes into picture and that is to help businesses to find out their competitive advantages by offering them comparison worksheets, which are totally practical and effective analysis tools.

\section{References}

[1] Butuner, H. (2017), "Practical Useful Techniques for Performing Strategic Internal Status Analysis", International Journal of Management Sciences and Business Research, 6 (1): 23-30.

[2] Butuner, H. (2016), "Shortened Systematic Strategic Planning (SSP): A Comprehensive Framework for Developing Strategies", Istanbul University Journal of the School of Business, 27 (80): 96-135. 
[3] Hitt, M. A., Ireland, R. D. and Hoskisson, R. E. (2005), Strategic Management: Competitiveness and Globalization, South-Western Thomson, Mason.

[4] Humble, A. and Radina, E. (2018), How Qualitative Data Analysis Happens, Routledge, New York.

[5] Keown, A. J. and Martin, J. (2011), Financial Management: Principles and Applications, Prentice Hall, New Jersey.

[6] Kotler, P. (2002), Marketing Management: Analysis, Planning, Implementation and Control, Prentice Hall, New Jersey.

[7] Nickels, W. G., McHugh, J. M. and McHugh, S. M. (2002), Understanding Business, McGraw- Hill Higher Education, Columbus.
[8] Parnell, J. A. (2013), Strategic Management: Theory and Practice, Saga Publications, London.

[9] Pearce, J. and Robinson, R. (2011), Strategic Management: Formulation, Implementation and Control, McGraw-Hill Higher Education, Columbus.

[10] Porter, M. E. (1998), Competitive Advantage, Free Press.

[11] Vernon, R. (1979), "The Product Cycle Hypothesis in a New International Environment", Oxford Bulletin of Economics and Statistics, 41 (4): 255-267.

[12] Wickham, P. A. (2006), Strategic Entrepreneurship, Pearson Education Limited, London. 